\section{Addition of Chlorhexidine Gluconate to a Glass Ionomer Cement: A Study on Mechanical, Physical and Antibacterial Properties}

Luana Mafra Marti, Margareth da Mata, Beatriz Ferraz-Santos, Elcilaine Rizzato Azevedo, Elisa Maria Aparecida Giro, Angela Cristina Cilense Zuanon
Department of Pediatric Dentistry and Orthodontics, Araraquara School of Dentistry, UNESP - Univ Estadual Paulista, Araraquara, SP, Brazil

Correspondence: Profa. Dra. Angela Cristina Cilense Zuanon, Rua Humaitá, 1680, 14801-903 Araraquara, SP, Brasil. Tel.: 55-16-3301-6335. e-mail: aczuanon@foar.unesp.br

\begin{abstract}
The objective of this work was to determine the effect of different concentrations of chlorhexidine digluconate $(\mathrm{CHX})$ on setting time, surface hardness, maximum tensile bond strength and antibacterial activity of a glass ionomer cement (GIC). The material used as control was Ketac Molar Easymix GIC. CHX was incorporated into the GIC during its manipulation at concentrations of $0.5,1.0$ and $2.0 \%$. Antimicrobial activity against $S$. mutans and L. acidophilus was evaluated by means of agar diffusion test. Tensile bond strength data were analyzed statistically using Analysis of variance and Tukey's test. Setting time, Vickers hardness and agar diffusion test were analyzed using KruskalWallis and Mann-Whitney tests at a significance level of 5\%. It was observed that adding $\mathrm{CHX}$ at concentrations of $1 \%$ and $2 \%$ increased significantly the setting time of the material ( $p=0.012$ and $p=0.003$, respectively). There was no significant difference between control and $0.5 \% \mathrm{CHX}$ groups regarding the setting time. Addition of $2 \% \mathrm{CHX}$ decreased significantly the surface hardness in relation to the control group $(p=0.009)$, followed by the $1 \%$ CHX group $(p=0.009)$. The tensile bond strength of the material also decreased significantly after adding $\mathrm{CHX}$ at a concentration of $2 \%(p=0.001)$. Addition of $\mathrm{CHX}$ promoted formation of an inhibition halo in both bacterial strains for all concentrations. The results showed that the best option for clinical use of GIC with $\mathrm{CHX}$ is at $0.5 \%$ concentration, since antibacterial activity increased and the physicalmechanical properties remained unchanged.
\end{abstract}

Key Words: glass-ionomer cement, chlorhexidine, compressive strength.

\section{Introduction}

Despite the continuous advance of the preventive and technological methods, the caries disease still has a high prevalence and epidemiological studies show that populations at high social risk are the most affected by such an oral condition (1).

The atraumatic restorative treatment (ART) is an option of dental treatment providing assistance to the most vulnerable populations, thus having a high impact on public health, as prevention and treatment are offered to a large segment of the world's population at low cost; (2). This technique is based on the philosophy of minimal intervention and consists of removing the infected dentin by manual instruments, followed by filling the cavity with adhesive restorative material, preferably the glass ionomer cement (GIC) (3). It is considered is a trusted and effective approach to the control of carious lesions (4).

The judicious application of the technique, respecting the physical-chemical properties of the restorative material and removing adequately the carious tissue, is fundamental for a successful treatment. Studies reported that the prevalence rates of secondary caries for 3 to 6 years were $1.5 \%$ and $2.4 \%(5,6)$, and that the percentage of restoration failures in permanent dentition ranged from 4 to $5 \%$, which represents a good technical result (7).

New techniques have been tested in an attempt to decrease failures and unsuccessful treatments. Studies investigating the use of antimicrobial agents, more specifically the $\mathrm{CHX}$ digluconate, in combination with restorative materials for reducing the frequency and severity of secondary caries are being developed in vitro (8-10) and in vivo (11).

Despite the promising results regarding the antibacterial effect of the combination of $\mathrm{CHX}$ and $\mathrm{GIC}$, a decrease in the mechanical properties of the cement has been reported $(10,12,13)$.

Studies have revealed that the higher the concentration of $\mathrm{CHX}$ added to the GIC, the greater the decrease in its physical-mechanical properties $(10,13)$. In view of this, the objective of the present work was to determine the effect of adding different concentrations of $\mathrm{CHX}$ to GIC on setting time, surface hardness, maximum tensile bond strength and antibacterial activity of the cement.

\section{Material and Methods}

For assessment of setting time, surface hardness, 
maximum tensile bond strength and antibacterial activity, CHX digluconate (Sigma Aldrich, Steinheim, Germany) was added to GIC during its mixing at concentrations of $0.5 \%, 1.0 \%$, and 2.0. The material used was Ketac Molar Easymix GIC (3M ESPE, Seefeld, Bavaria, Germany), prepared according to the manufacturer's instructions at room temperature $\left(23 \pm 1^{\circ} \mathrm{C}\right)$ and relative humidity of $50 \pm 5 \%$.

The number of specimens for each group was determined based on the similarity of values obtained in a pilot study and the steps are presented in the form of a flowchart (Fig. 1).

\section{Setting Time}

For preparation of the samples, the material was inserted into metallic matrices (10 $\mathrm{mm}$ diameter $\times 1 \mathrm{~mm}$ dep) by means of a Centrix syringe (DFL Indústria e Comércio S.A., Rio de Janeiro, RJ, Brazil). Next, the material was covered with a polyester tape and a 1-mm thick glass slide, on which a $100 \mathrm{~g}$ weight was placed for $10 \mathrm{~s}$ for accommodation and elimination of excess material.

A Gilmore needle weighing $400 \pm 5 \mathrm{~g}$ was carefully placed on the surface of the material perpendicularly and left there for $5 \mathrm{~s}$. The process was repeated at $10 \mathrm{~s}$ intervals and the circular marks left by the needle on the surface were examined. The setting time was determined when these circular marks were no longer observed (ISO 6876/2001).

\section{Surface Hardness}

The samples were obtained from a Teflon matrix (7 $\mathrm{mm}$ diameter $\mathrm{x} 4 \mathrm{~mm}$ deep) with a central orifice through which the material was inserted using a Centrix syringe. Next, the same procedures described above were performed.

Vickers hardness (VNH) was analyzed with a digital micro-hardness tester (Micromet 2100; Buehler Ltd., Lake Bluff, IL, USA) using a 50-gf load for $30 \mathrm{~s}$ applied to four quadrants of the samples. Two impressions were made on the quadrants with a distance of $100 \mu \mathrm{m}$ between them,

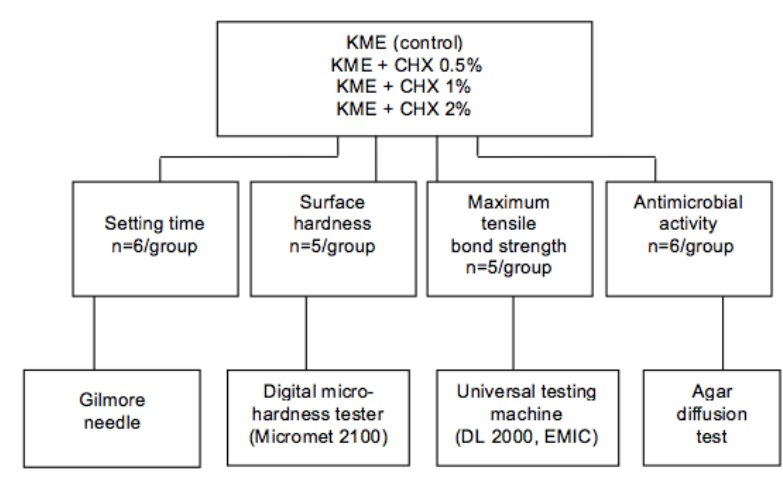

Figure 1. Flowchart of the experimental steps in each group. KME: Ketac Molar Easymix. CHX: Chlorhexidine. totalizing 8 values from each the mean value of hardness for each sample was calculated.

\section{Maximum Tensile bond Strength}

The samples obtained from a cylindrical polyester matrix (8 $\mathrm{mm}$ diameter $\times 6 \mathrm{~mm}$ high) were filled with two increments of GIC. The material was covered with a polyester tape and then submitted to digital pressure for $2 \mathrm{~s}$ in order to better accommodate the material.

After $1 \mathrm{~h}$ from the initial manipulation of the materials, the samples were removed from the matrix and stored in an oven for $24 \mathrm{~h}$ at $37 \pm 1{ }^{\circ} \mathrm{C}$ and $90 \pm 5 \%$ relative humidity.

The samples were attached to a wooden base with a lowfusing compound and then submitted to a cutting machine (Isomet 1000; Buehler Ltd.) equipped with a diamond disk $0.5 \mathrm{~mm}$ thick (Diamond Wafering Blade; Buehler Ltd.) operating with a $200-\mathrm{gf}$ load at a speed of $250 \mathrm{rpm}$ under constant cooling to produce 1-mm thick sections After a 90-degree rotation of the sample, a new series of cuts was performed according to the same protocol. In the end, stick-shaped samples were obtained, and the quadrangular cross-sectional area measured approximately $1 \mathrm{~mm}^{2}$.

Each stick was carefully inspected with a stereoscopic magnifying glass (Modelo SZX7; Olympus, São Paulo, SP, Brazil) and all samples presenting irregularities or air bubbles were discarded. The selected samples had their cross-sectional area measured by a digital calliper (Mod. 500-144B; Mytutoyo Sul Americana Ltda., São Paulo, $\mathrm{SP}$, Brazil) with 0.01-mm resolution, for calculating the maximum tensile bond strength values.

For the micro-tensile bond test, cyanoacrylate adhesive (Super Bonder 7456; Henkel Loctite Ltda, São Paulo, SP, Brazil) was used to attach the sticks individually to a metallic device adapted to a universal testing machine (DL 2000; EMIC Equipamentos de Ensaio Ltda, Curitiba, PR, Brazil), previously adjusted with a $1 \mathrm{kN}$ load cell at a cross-head speed of $0.5 \mathrm{~mm} / \mathrm{min}$. The tensile bond movements were initiated by a specific software (Tesc - Test Script; EMIC Equipamentos de Ensaio Ltda), and the values of maximum load were recorded after rupture of the samples. The maximum tensile bond strength values ( $\mathrm{MPa}$ ) were obtained by dividing the maximum load by the cross-sectional area of each sample.

\section{Antibacterial Activity}

The antibacterial activity was assessed by the agar diffusion test using the following microorganisms: Streptococcus mutans (ATCC 25175) and Lactobacillus acidophilus (ATCC 4356) from the Tropical Culture Collection of the Fundação Tropical de Pesquisas e Tecnologias Andre Tosello (Campinas, SP, Brazil), provided by the Araraquara School of Dentistry Microbiology Laboratory. All procedures 
were performed under aseptic conditions in a vertical laminar flow hood (PA-115; Pachane, Piracicaba, São Paulo, SP, Brazil).

Initially, the standard bacterial strains were reactivated with $5 \mathrm{~mL}$ sterile brain heart infusion broth (BHI; Difco Laboratories, Detroit, MI, USA). Next, both strains were selected from the culture gain and inserted into a test tube containing $5 \mathrm{~mL}$ of BHI broth. After gently shaking the test tube, it was placed in a bacteriological oven (FANEM Ltda., São Paulo, SP, Brazil) at $37^{\circ} \mathrm{C}$ for $24 \mathrm{~h}$ under microaerophilic conditions using hermetically closed jars. After the growth of microorganisms, the suspension was centrifuged and washed twice with sterile phosphatebuffered saline (BPS) and the resulting solution had its turbidity adjusted with a spectrophotometer (Eppendorf AG, Hamburg, Germany) until reaching absorbency of 0.30 at $600 \mathrm{~nm}$, which corresponds to a stock solution suspension of $1 \times 10^{7} \mathrm{CFU} / \mathrm{mL}$.

In each step of the diffusion test, six Petri plates (150 $\mathrm{mm} \times 15 \mathrm{~mm}$ ) were used for each organism. In each plate were poured $25 \mathrm{~mL}$ of $\mathrm{BHI}$ agar at $50{ }^{\circ} \mathrm{C}$ plus $240 \mathrm{~mL}$ of bacterial inoculate $\left(1 \times 10^{7} \mathrm{CFU} / \mathrm{mL}\right)$ until reaching a $5-\mathrm{mm}$ thickness. After solidification (approximately $30 \mathrm{~min}$ ), four pools ( $4 \mathrm{~mm}$ diameter and $5 \mathrm{~mm}$ depth) were made in

Table 1. Values of setting time ( $\mathrm{min}$ ), surface hardness (VHN) and maximum tensile bond strength (MPa) according to the materials used

\begin{tabular}{lccc}
\hline Material & $\begin{array}{c}\text { Median setting } \\
\text { time (min-max) } \\
\mathrm{n}=6\end{array}$ & $\begin{array}{c}\text { Median surface } \\
\text { hardness } \\
(\text { min-max }) \mathrm{n}=5\end{array}$ & $\begin{array}{c}\text { Mean maximum tensile } \\
\text { bond strength (std. } \\
\text { deviation) } \mathrm{n}=5\end{array}$ \\
\hline $\mathrm{KME}$ & $5.15(5.00-6.30)^{\mathrm{a}}$ & $33.40(32.29-34.81)^{\mathrm{a}}$ & $10.46(1.85)^{\mathrm{a}}$ \\
$\mathrm{KME}+0.5 \% \mathrm{CHX}$ & $6.10(5.50-6.30)^{\mathrm{a}}$ & $32.91(31.73-34.99)^{\mathrm{a}}$ & $8.05(1.75)^{\mathrm{ab}}$ \\
$\mathrm{KME}+1 \% \mathrm{CHX}$ & $6.65(6.00-7.30)^{\mathrm{b}}$ & $27.89(24.18-29.76)^{\mathrm{b}}$ & $8.33(0.84)^{\mathrm{a}}$ \\
$\mathrm{KME}+2 \% \mathrm{CHX}$ & $10.15(10.00-11.00)^{\mathrm{c}}$ & $14.41(11.46-15.16)^{\mathrm{c}}$ & $5.65(0.74)^{\mathrm{b}}$ \\
\hline
\end{tabular}

KME: Ketac Molar Easymix. CHX: Chlorhexidine. Different lowercase letters in columns indicate statistically significant difference $(p<0.05)$.

Table 2. Diameter of the inhibition halo $(\mathrm{mm})$ obtained according to the concentration of chlorhexidine digluconate added to the glass ionomer cement and bacterial strains (median, minimum and maximum)

\begin{tabular}{|c|c|c|}
\hline \multirow{2}{*}{ Material } & \multicolumn{2}{|c|}{ Microorganism } \\
\hline & L. casei $(\mathrm{n}=6)$ & S. mutans $(n=6)$ \\
\hline KME & $0(0-0)$ bA & $0(0-0) \mathrm{bA}$ \\
\hline $\mathrm{KME}+0.5 \% \mathrm{CHX}$ & $15.07(14.58-17.27)^{\mathrm{aA}}$ & $13.85(13.15-14.25) \mathrm{aB}$ \\
\hline $\mathrm{KME}+1 \% \mathrm{CHX}$ & $15.11(14.61-17.17)^{\mathrm{aA}}$ & $13.74(13.30-14.90)$ ав \\
\hline $\mathrm{KME}+2 \% \mathrm{CHX}$ & $15.45(14.13-17.38)$ aA & $14.21(13.12-14.69) \mathrm{aB}$ \\
\hline
\end{tabular}

KME:Ketac Molar Easymix. CHX:Chlorhexidine. Different uppercase letters in rows and lowercaselettersin columnsindicatestatisticallysignificant difference $(\mathrm{p}<0.05)$. each plate using the tip of a sterilized Pasteur pipette so that each plate could receive the material with different concentrations of $\mathrm{CHX}$. The pools were $3-4 \mathrm{~cm}$ distant from each other and about $2.5 \mathrm{~cm}$ from the plate border. The materials were manipulated under aseptic conditions and then fully inserted into pools made in the Petri plates using a Centrix syringe.

For pre-diffusion of the materials, the plates were kept at room temperature for $1 \mathrm{~h}$ and then incubated at $37 \pm$ $1^{\circ} \mathrm{C}$ for $48 \mathrm{~h}$ in anaerobiosis jars under microaerophilic conditions. Next, the diameter of the inhibition halos around the samples was measured by using a digital caliper (Mytutoyo Sul Americana Ltda.) based on two opposite points located at the most external limits. In order to ensure absence of bacterial growth in the region corresponding to the halos, the plates were assessed with a light microscope (Model VT-II; Olympus, Tokyo, Japan) at 20x magnification.

\section{Statistical Analysis}

Data on maximum tensile bond strength had normal distribution and variance homogeneity, thus analysis of variance and Tukey's test were applied to them. Data on setting time, Vickers hardness and inhibition halo showed normal distribution, so Kruskal-Wallis and MannWhitney tests were applied to them. Significance level was set at $5 \%$.

\section{Results}

The values of setting time, Vickers hardness, and maximum tensile bond strength for each concentration of chlorhexidine digluconate are in Table 1.

Addition of $\mathrm{CHX}$ at concentrations of $1 \%$ and $2 \%$ resulted in a statistically significant increase for the setting time ( $p=0.012$ and $p=0.003$, respectively) of Ketac Molar Easymix GIC. There was no significant difference between the control and $0.5 \% \mathrm{CHX}$ groups regarding the setting time $(\mathrm{p}=0.072)$.

The $2 \%$ CHX group had a statistically significant decrease in surface hardness compared to control group ( $p=0.009$ ), followed by the $1 \% \mathrm{CHX}$ group $(p=0.009)$. The Ketac Molar Easymix GIC mixed with $0.5 \%$ CLX had no significant difference in Vickers hardness compared to the control group $(p=0.754)$.

Only the Ketac Molar Easymix GIC containing 2\% CHX had a statistically significant decrease in the tensile bond strength compared to control group $(p=0.001)$.

Table 2 displays the median values, as well as the 
minimum and maximum values of the inhibition halos for each studied group, according to the bacterial strain.

Ketac Molar Easymix without CHX (control) had no antibacterial activity for both microorganisms. The action of chlorhexidine digluconate promoted the formation of inhibition halos for both bacterial strains, statistically greater for $L$. casei than for S. mutans $(p<0.05)$ for all CHX concentrations (Table 2).

Increasing the $\mathrm{CHX}$ concentration in the $\mathrm{GIC}$ from $0.5 \%$ to $2.0 \%$ resulted in no significant increase in the diameter of the inhibition halo for $L$. casei and S. mutans $(p=0.16$ and $p=0.46$, respectively).

\section{Discussion}

GICs are mainstream bioactive restorative materials and have a wide range of uses such as luting, bonding or restoring a tooth. It is important to recognize that although the GICs share the same general properties, subtle differences among commercial products may occur (14).

High-viscosity GIC is the material of choice for the ART technique, since it adheres chemically to the dental structures and releases fluoride, which not only contributes to the reduction in the amount of residual bacteria in the affected dentin (10).

GICs release approximately $10 \mathrm{ppm}$ of fluoride during the first $48 \mathrm{~h}$ following insertion into the cavity (16), but this figure is still regarded low for achieving the desired antibacterial effects (10). In order to improve the antibacterial characteristics of this material, chlorhexidine in the form of powder (chlorhexidine digluconate) has been added to it $(13,17,18)$.

This study used the agar diffusion test to assess the antibacterial action of the GIC containing $\mathrm{CHX}$ at different concentrations. It was found that adding $\mathrm{CHX}$ to GIC promoted inhibition of bacterial growth, being more effective for $L$. Casei than S. muntans, a finding corroborating previous studies $(9,10,12,13)$.

Similarly to the findings of previous investigations $(9,10)$, no dose-dependent effect was observed in the present study, that is, the inhibition halos were not dependent on the concentration of $\mathrm{CHX}$ added to GIC, differently from the studies by Botelho (17), Ribeiro, Ericson (19) and de Castilho (20).

It is known that a large number and variety of bacteria is related to caries development. According to Yap et al. (21), GIC does not promote an efficient antibacterial effect despite the presence of fluoride, and the addition of $0.5 \%$ $\mathrm{CHX}$ improves the antimicrobial properties of the material (12). However, addition of chlorhexidine digluconate at different concentrations can interfere with physical and mechanical properties of the GIC (9).
The ability of a restorative material to resist masticatory forces is an important aspect for its long-term clinical performance. According to Sanders et al. (12), addition of CHX to GIC should produce better antimicrobial activity as well as physical and mechanical properties comparable to the original material.

An important factor influencing the mechanical properties of the GIC is the powder/liquid ratio of the mixture and addition of CHX may alter this proportion and consequently the mechanical and physical resistance of the material $(9,12,13)$.

The micro-tensile bond test is indicated for materials with low tensile bond resistance (10) as the GIC, because it allows samples with small sectional area to be adequately tested and the risk of concentration of structural defects is reduced. This risk can affect the distribution of tensional forces acting on the sample, causing failures resulting from a force smaller than the actual intrinsic resistance of the material $(22,23)$.

In the present experiment, $\mathrm{CHX}$ promoted a statistically significant decrease in tensile bond strength only at the $2 \%$ concentration $(p=0.001)$. Sanders et al. (18) and Türkün et al. (13) showed that the decrease in the physical properties of GICs modified by CHX digluconate (liquid) is related to the fact that $\mathrm{CHX}$ is solubilized faster into the external environment than in the form of $\mathrm{CHX}$ powder or diacetate. However, in another study (10), CHX salts hamper the reaction between the acid and glass particles, thus increasing the setting time proportionally to the concentration of CHX. As observed by Prosser et al. (24), the amines present in the $\mathrm{CHX}$ molecule neutralize the polyacid during salt formation and consequently may interfere with the setting time. This occurs because the basic compounds neutralize the capacity of polyacids to release ions from glass particles. However, the increase in setting time is caused by the formation of base/polyacid complexes that block cross-reactions between cationic ions and poly-acrylic chains. The duration of the setting time depends on the formation of base/polyacid complexes that block cross-reactions between cationic ions and polyacrylic chains (24).

In this study, no significant difference in setting time was observed between the control group and that of 0.5\% CHX digluconate. Addition of $\mathrm{CHX}$ digluconate at concentrations of $1 \%$ and $2 \%$ resulted in an increased setting time of the GIC, which may be attributed to the low water solubility of the $\mathrm{CHX}$ digluconate (12), as well as to the presence of cationic salts, since they block the glass particles to react with poly-acrylic acids (10).

The hardness is also related to the wear resistance of the material to the wear resulting from masticatory efforts, eating and tooth brushing, among others (25). In this 
study, it was found that the decrease in surface hardness is proportional to the increase in the $\mathrm{CHX}$ concentration, because of the changes in the powder/liquid ratio (17). However, the addition of $\mathrm{CHX}$ at low concentrations, such as $0.5 \%$, had no interference with setting time, maximum tensile bond resistance and surface hardness of the material $(9,10,12,13)$. In conclusion, for clinical use of GIC with $\mathrm{CHX}$, the best option is the addition of $\mathrm{CHX}$ at a concentration of $0.5 \%$, since this combination increased the antibacterial activity without changing the physicalmechanical properties of the material.

\section{Resumo}

0 objetivo deste trabalho foi determinar o efeito de diferentes concentrações de gluconato de clorexidina (CLX) sobre o tempo de presa, dureza superficial, resistência máxima a tração e atividade antibacteriana de um cimento de ionômero de vidro (CIV). 0 material utilizado como controle foi o CIV Ketac Molar Easymix. 0 gluconato de CHX foi incorporado no CIV durante a sua manipulação, em concentrações de $0,5,1,0$ e 2,0\%. Atividade antimicrobiana contra S. mutans e L. acidophilus foi avaliada por meio de teste de difusão em ágar. Análise de variância (ANOVA) e teste de Tukey foram usadas para avaliar a resistência a tração do material. Para avaliar tempo de presa, dureza Vickers e teste de difusão em ágar foram usados os testes de Mann-Whitney e Kruskal-Wallis ao nivel de significância de $5 \%$. Observou-se que a adição de CHX, em concentrações de $1 \%$ e $2 \%$, aumentou significativamente o tempo de presa do material $(p=0,012$ e $p=0,003$, respectivamente). Não houve diferença significativa entre os grupos controle e $\mathrm{CHX} 0,5 \%$ em relação ao tempo de presa. A adição de $2 \%$ de $\mathrm{CHX}$ diminuiu significativamente a dureza superficial, em relação ao grupo controle $(p=0,009)$, seguido pelo grupo $1 \%$ de $\operatorname{CHX}(p=0,009)$. A resistência à tração do material também diminuiu significativamente após a adição de $\mathrm{CHX}$ a uma concentração de $2 \%$ ( $p$ $=0,001)$. A adição de CHX promoveu formação de halo de inibição em ambas as linhagens bacterianas para todas as concentrações. Os resultados mostraram que a melhor opção para o uso clínico de CIV com CHX está numa concentração de 0,5\%, uma vez que a atividade antibacteriana aumentada e as propriedades físico-mecânicas permaneceram inalteradas..

\section{References}

1. Sanders AE, Slade GD, Turrell G, Spencer JA, Marcenes W. The shape of the socioeconomic-oral health gradient: implications theoretical explanations. Community Dent Oral Epidemiol 2006;34:310-319.

2. Schriks MCM, van Amerongen WE. Atraumatic perspective of ART: psychological and physiological aspects of treatment with and without rotary instruments. Community Dent Oral Epidemiol 2003;31:15-20.

3. Frencken JE, Leal SC. The correct use of the ART approach. J Appl Oral Sci 2010;18:1-4.

4. Holmgren CJ, Roux D, Doméjean S. Minimal intervention dentistry: part 5. Atraumatic restorative treatment (ART) - a minimum intervention and minimally invasive approach for the management of dental caries. Br Dent J 2013;214:11-18.

5. Frencken JE, Taifour D, van't Hof MA. Survival of ART and amalgam restorations after 6.3 years. J Dent Res 2006;85:622-626.

6. Lo ECM, Holmgren CJ, Hu D, Wan H, van Palenstein Helderman W. A six-year study of ART restorations placed in Chinese school children. Community Dent Oral Epidemiol 2007,35:387-392.
7. Frencken $J E_{1}$ Van't Hof MA, Van Amerongen WE, Holmgren CJ. Effectiveness of single-surface ART restorations in the permanent dentition: a meta-analysis. J Dent Res 2004;83:120-123.

8. Hoszek A, Ericson D. In vitro fluoride release and the antibacterial effect of glass ionomers containing chlorhexidine gluconate. Oper Dent 2008;33:696-701.

9. Jedrychowski J, Caputo A, Kerper S. Antibacterial and mechanical properties of restorative materials combined with chlorhexidines. J Oral Rehab 1983;10:373-381.

10. Takahashi $\mathrm{Y}$, Imazato $\mathrm{S}$, Kaneshiro AV, Ebisu $\mathrm{S}$, Frencken JE, Tay FR. Antibacterial effects and physical properties of glass-ionomer cements containing chlorhexidine for the ART approach. Dent Mater 2006;22:647-652.

11. Frencken JE, Imazato S, Toi C, Mulder J, Mickenautsch S, Takahashi $Y$ et al.. Antibacterial effect of chlorhexidine-containing glass ionomer cement in vivo: a pilot study. Caries Res 2007;41:102-107.

12. Sanders BJ, Gregory RL, Moore K, Avery DR. Antibacterial and physical properties of resin modified glass-ionomers combined with chlorhexidine. J Oral Rehabil 2002;29:553-558.

13. Türkün $L S$, Türkün $M$, Ertugrul $F$, Ates $M$, Brugger $S$. Long-term antibacterial effects and physical properties of a chlorhexidinecontaining glass ionomer cement. J Esthet Restor Dent 2008;20:29-44.

14. Sidhu SK. Glass-ionomer cement restorative materials: a sticky subject? Aust Dent J 2011;56 S1:23-30.

15. Massara ML, Alves JB, Brandao PR. Atraumatic restorative treatment: clinical, ultrastructural and chemical analysis. Caries Res 2002;36:430436.

16. Mazzaoui SA, Burrow MF, Tyas MJ. Fluoride release from glass ionomer cements and resin composites coated with dentin adhesive. Dent Mater 2000;16:166-171.

17. Botelho MG. Inhibitory effects on select oral bacteria of antibacterial agents incorporated in a glass ionomer cement. Caries Res 2003;37:108-114.

18. van Strijp AJ, van Steenbergen TJ, ten Cate JM. Effects of chlorhexidine on the bacterial colonization and degradation of dentin and completely demineralized dentin in situ. Eur J Oral Sci 1997;105:27-35.

19. Ribeiro J, Ericson D. In vitro antibacterial effect of chlorhexidine added to glass-ionomer cements. Scand J Dent Res 1991;99:533-540.

20. de Castilho AR, Duque $C$, Negrini T de C, Sacono NT, de Paula AB, de Souza Costa $C A$, et al.. In vitro and in vivo investigation of the biological and mechanical behaviour of resin-modified glass-ionomer cement containing chlorhexidine. J Dent 2013;41:155-163.

21. Yap AU, Khor E, Foo SH. Fluoride release and antibacterial properties of new-generation tooth-colored restoratives. Oper Dent 1999;24:297305.

22. Pashley DH, Carvalho RM, Sano H, Nakajima M, Yoshiyama M, Shono $Y$, et al.. The microtensile bond test: a review. J Adhes Dent 1999;1:299309.

23. Carvalho RM, Sano H, Ciucchi B, Yoshiana M, Pashley DH. Bond strength dentine determined by a new developed micro-tensile testing device. Rev FOB 1994:2:77-82.

24. Prosser $\mathrm{HJ}$, Jerome $\mathrm{SM}$, Wilson $\mathrm{AD}$. The effect of additives on the setting properties of a glass-ionomer cement. J Dent Res 1982;61:1195-1198.

25. Shintome LK, Nagayassu MP, Di Nicolo R, Myaki SI. Microhardness of glass-ionomer cements indicated for the ART technique according to surface protection treatment and storage time. Braz Oral Res 2009;23:439-445. 